\title{
Conservation of Intangible Cultural Heritage of Dyeing Skills: Challenges and Strategy in Kofar Mata Dyeing Pits Industry, Kano, Nigeria
}

Abubakar Sadiq Young, Asnarulkhadi Abu Samah, Mohd Roslan Rosnon \& Sarjit Singh Darshan Singh

To Link this Article: http://dx.doi.org/10.6007/IJARBSS/v11-i12/11943

DOI:10.6007/IJARBSS/v11-i12/11943

Received: 05 October 2021, Revised: 09 November 2021, Accepted: 29 November 2021

Published Online: 26 December 2021

In-Text Citation: (Young et al., 2021)

To Cite this Article: Young, A. S., Samah, A. A., Rosnon, M. R., \& Singh, S. S. D. (2021). Conservation of Intangible Cultural Heritage of Dyeing Skills: Challenges and Strategy in Kofar Mata Dyeing Pits Industry, Kano, Nigeria. International Journal of Academic Research in Business and Social Sciences, 11(12), 21732189.

\section{Copyright: (c) 2021 The Author(s)}

Published by Human Resource Management Academic Research Society (www.hrmars.com) This article is published under the Creative Commons Attribution (CC BY 4.0) license. Anyone may reproduce, distribute, translate and create derivative works of this article (for both commercial and non0-commercial purposes), subject to full attribution to the original publication and authors. The full terms of this license may be seen

at: http://creativecommons.org/licences/by/4.0/legalcode

Vol. 11, No. 12, 2021, Pg. 2173- 2189

Full Terms \& Conditions of access and use can be found at http://hrmars.com/index.php/pages/detail/publication-ethics 


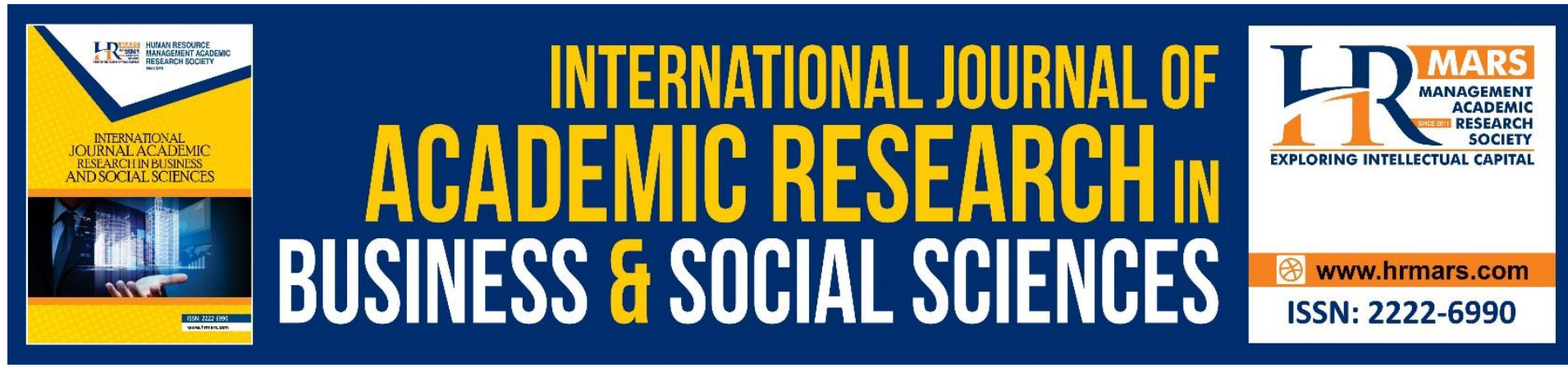

\title{
Conservation of Intangible Cultural Heritage of Dyeing Skills: Challenges and Strategy in Kofar Mata Dyeing Pits Industry, Kano, Nigeria
}

\author{
Abubakar Sadiq Young ${ }^{1,3}$, Asnarulkhadi Abu Samah ${ }^{1,2}$, Mohd \\ Roslan Rosnon ${ }^{1} \&$ Sarjit Singh Darshan Singh ${ }^{1}$ \\ ${ }^{1}$ Department of Social and Developmental Science, Faculty of Human Ecology, Universiti \\ Putra Malaysia, Serdang, ${ }^{2}$ Institute for Social Science Studies, Universiti Putra Malaysia, \\ Serdang, ${ }^{3}$ National Gallery of Art, Abuja, Nigeria \\ Email: asnarul@upm.edu.my
}

\begin{abstract}
Dyeing an intangible Cultural Heritage (ICH) embodied in traditional crafts is an integral part of the Nigerian people since the pre-colonial period. This practice continued into the postcolonial era, which had since evolved beyond the socio-cultural aspects to include the economic aspects. In recent years, however, there is increasing decline in the practice of this art in most parts of the country. Though practices in the dyeing industry have been widely recognized, literature regarding conservation of this important traditional skill remains scarce. This paper intends to explore and identify challenges faced by craft workers in the dyeing industry with focus on of the renowned Kofar Mata Dye Pits in Kano, Nigeria. Empirical data was collected through in-depth interviews and focus group discussion from diverse participants that included ICH dyers, government authorities, community leaders, marketers and consumers. Our study identified a number of issues threatening the preservation of this important cultural heritage. Strategies to promote and preserve this intangible cultural heritage to ensure its sustainability were also shared.
\end{abstract}

Keywords: Dyeing, Intangible Cultural Heritage, Kofar Mata, Nigeria, Conservation

\section{Introduction}

Dyeing is an intangible cultural heritage (ICH) and at the same time a tacit dimension of knowledge part of the arts and craft profession that's shared through experiences according to Shimray and Ramaiah (2020). The ICH dyeing skill is widely practised around the globe in many cultures since civilisation. Although there is inadequate empirical account of the origin of the dyeing profession around the world. Committee on the Survey of Materials Science, (1975), mentioned in one of its research works, "Materials and Man's Needs: Materials Science and Engineering; Supplementary Report", that initially natural dye existence many centuries ago and its information was spread by word-of-mouth, and in some cases, in rough manuscripts that literary custodian will consider such not worth keeping, according to US (National Academy of Sciences, 1975). However, the natural dye first appearance in literature 
1548 in Venice as stated in (Morris and Travis, 1992). The increasing literature works demonstrate that natural indigo dyes centuries existence acknowledged the popular belief that this tacit skill knowledge (Polanyi and Sen, 2009) of dyeing emerged alongside the history of man, since it has become worthy for literary custodian to keep track of it, in the contemporary society. After the discovery of the British Chemist Henry Perkin's Mauveine dye around 1856, the synthetic dye subsequently began to replace the indigo dye in commercial quantity (Gupta, 2019). Growing literatures (Budiastuti et al., 2021; Dey, 2010; Mishra, 2021; Bechtold \& Mussak, 2009; Hawkins \& Havens, 2008) indicates that this breakthrough in synthetic dye couple with the climate change phenomenon has become a threat to the natural or indigo plants is invariably becoming scarce and also adversely affecting the ICH dyeing skill profession.

For many countries, their intangible cultural heritage (hence refer to as $\mathrm{ICH}$ ) is reflected in their handicrafts such as dyeing; and played a vital role in income and employment generation (Abisuga-Oyekunle and Fillis, 2017). The ICH dyeing industry in Nigeria played a significant role in income generation and employment among others. However, with the increasing technological advancement, modernisation and mass production, associated to the industrialize dyeing as noted in Oláh et al (2020); and Nagy et al (2018), this tacit skill craft of dyeing fabrics is incomparably finding it difficult to favourably compete with the modernized dyed imported textiles. This necessitated the recently outcry, for the conservation on the deteriorating heritage skill practices generally in several parts of Nigerian communities and in particular the ICH dyeing industry of Kofar Mata Kano. The arts and skills of dyeing has faced several challenges in recent times due to industrialization and globalization (Gazzola et.al., 2020; Roblek et al., 2020).

This consequentially resulted in the inability of the craft workers to compete effectively with organized modern market. More so, changes in lifestyle and customer's needs, has resulted in low patronage of such heritage products; as such, most craft workers were left with no option than changing their paradigm shift to engage in other sources of income as indicated by Li et. al (2019). This has resulted in somewhat neglect of several heritage practices, as few younger generations are interest in learning the skills (Leesuwan, 2010; Cohen, 2000). Despite these challenges, the practice of dyeing still remains crucial in promoting and sustaining the cultural heritage of the people as well as giving economic advantage to the community (UNESCO, 2017).

Not until recently, works on the conservation of $\mathrm{ICH}$ such as dyeing has remained scare, this is because, unlike the tangible heritage; $\mathrm{ICH}$ entails skills that has to be physically seen, to share the tacit knowledge as studies shows by Shimray and Ramaiah (2020), making it difficult to notice that it is gradually deteriorating or perhaps disappearing. The old fashion way of conservation which is still the present techniques that is training the younger generations, that would take over the skill practice from the older generations. Hence, to conserve this ICH dyeing tradition, it is very necessary to understand and address the challenges it faces (Yang et al., 2018). This study is aim to identify challenges faced by craftsmen, particularly Kofar Mata dyers, in the dyeing industry and provide practical suggestions that could help to resuscitate and sustain this importance heritage practice from total decay. This study was specifically focused on Kofar Mata ICH dyeing pit industry in Kano state Nigeria as it was one of the centres of beehive of activities in the ICH dyeing and Africas textile market power 
economy businesses as claimed by Johnson (1974; 1976), Candotti (2015), Lovejoy (2016), Kobayashi (2019).

\section{Literature Reviews \\ Intangible cultural Heritage in Nigeria}

Cultural heritage has changed considerably in recent times, to include not only built heritage such as monuments and collections of objects, but also includes knowledge, traditions or living expressions inherited from one generation to another. The concept of intangible cultural heritage $(\mathrm{ICH})$ emerged as a counterpart in the maintenances of physical culture, termed tangible heritage (Foster \& Saleh, 2021; Patru-Strupariu et al., 2019). Tangible culture includes all activities that can be touched, meanwhile intangible culture heritage are activities that cannot be touched, this includes activities such as songs, music, visitation to tourism sites, reading, art performance, drama culinary activities, and crafts kill among others (Yang et, al, 2018; Lin \& Lian, 2018; Yan \& Chiou, 2021).

Intangible cultural heritage includes any form of heritage practices that encompasses; expression, languages, performance, dance, song, music, and martial arts existing or had existed in a community as postulated by Eichler (2021), Harun (2011) and Mustafa and Saleh (2017). With the emergence of $\mathrm{ICH}$ as an important aspect in the maintenance of culture through UNESCO Convention for the safeguarding of the intangible cultural heritage in 2003 was aimed to raising awareness on the importance of $\mathrm{ICH}$ as indicated in their literatures of Kurin $(2004 ; 2007)$ and Blake (2008). As part of the Convention resolution, member states are required to prepare inventory of $\mathrm{ICH}$ with the participation of the concerned communities; adopt policies and establish institutions to monitor and promote it as well as take appropriate measures safeguard it (Yang et, al, 2018). The convention defined ICH as "the practices, representations, expressions, knowledge, skills as well as the instruments, objects, artefacts and cultural spaces associated with a community, groups and, in some cases, individuals recognize as their cultural heritage" [UNESCO. Convention for the Safeguarding of the Intangible Cultural Heritage 2003 (Unesco, 2019) and Yang et, al., (2018). According to the convention, $\mathrm{ICH}$ is classified into five broad domains: 1) traditional craftsmanship, oral traditional and expressions, performing arts, knowledge and practices concerning nature and universe, and social practices, rituals and festive events.

Intangible cultural heritage as an important driving force towards achieving cultural diversity and sustainability among communities and nations, has unfortunately suffered several cultural heritage setbacks. $\mathrm{ICH}$ as collective importance and values, has conceptually metamorphose globally as an Outstanding Universal Values (OUV) of peoples shared aspirations and collective memories as Labadi (2013) and Roders and Van Oers (2010) and Smith (2006). Since upon the contemporary 2003 UNESCO convention for the safeguarding of the Intangible Cultural Heritage towards promoting the community living heritage, there are some noticeable declining transitions of these ICH that urgently calls for action not only from their local communities or at national level but also calls for global action to be part. 


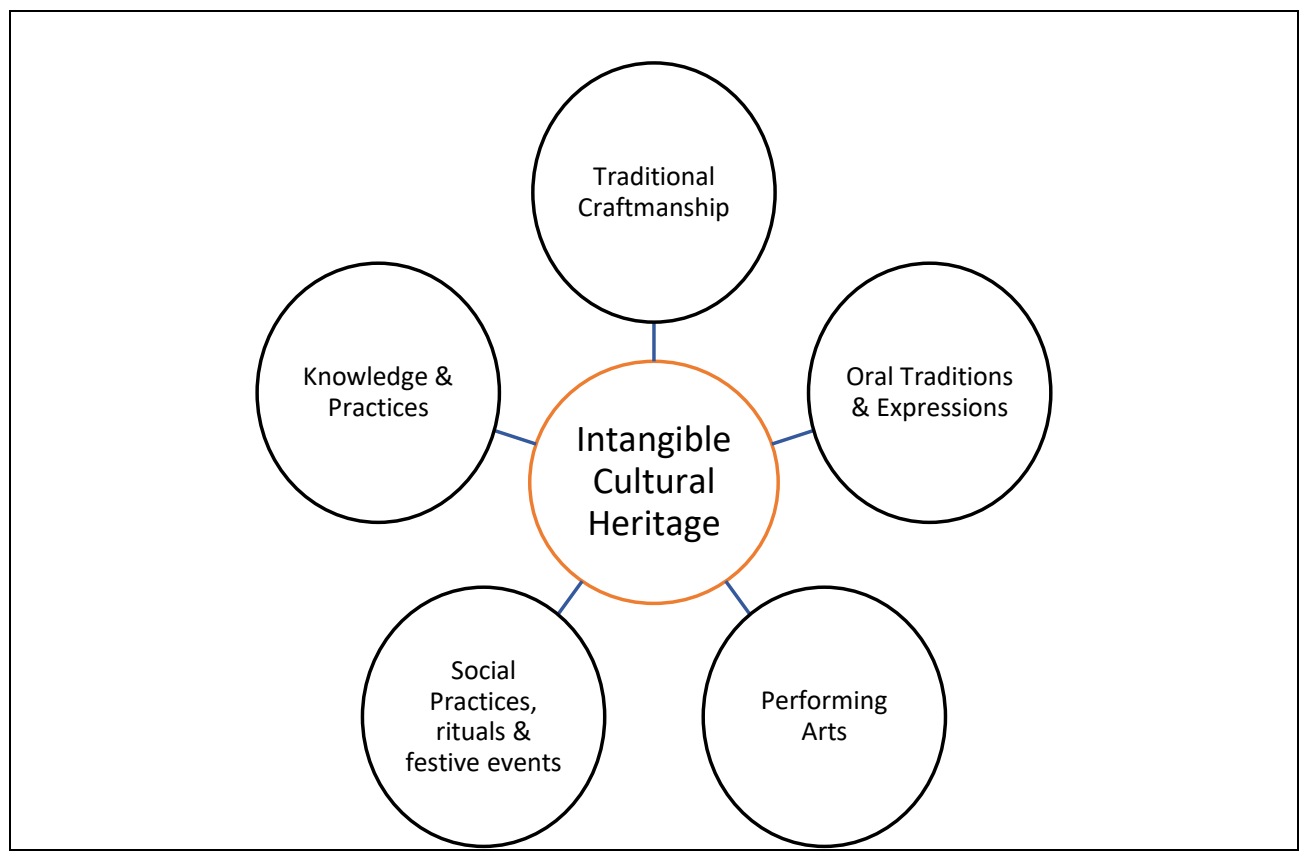

Figure1: $\mathrm{ICH} 5$ broad domains of $\mathrm{ICH}$

Source: Unesco 2003 Convention

In another development the systematic attacks on cultural heritage are deliberate in various controversial and ambiguous conflicts around the world has correspondingly pause a collateral damage on the living heritage (Smith \& Waterton, 2013; Miura, 2005; Kurin, 2004; Stefano, Davis \& Corsane, 2014). It is ambiguous to say the conflicts are politically motivated, looting and deliberate and intentional destruction of these proudly world heritage OUV (UNESCO, 2016). This deliberate destruction and looting of our living heritage can correspondingly be describe as deprivation, harassments or oppression of individuals human right on their cultural heritage be it cultural, ethnic or base on religious background. More so, it further means denying they people their cultural or community identity, which invariably result to mean 'cultural cleansing'. However, these destructive challenges great setback to cultural diversity (UNESCO, 2016), in safeguarding cultural heritage.

\section{Kofar Mata ICH Dyeing Kano}

An important ICH in Nigeria is the art of cloth dyeing known with different names across the diverse ethnic groups in the country. In the traditional cloth dyeing practices is also identified among communities in Northern Nigeria, particularly among communities in Kano state Nigeria. In these communities, the origin of dyeing, locally refer to as rini, existed alongside the history of Kano. Kano was said to exist long before the discovery of thermoluminescent iron smelting skill at about 320-380AD before becoming a state and political entity in 999AD (Olofin, 1987; Barau, 2007). Dyeing activities in Kano began as a result of their trading transaction with Berbers and Arabs from (North Africa Heathcote, 1976). More so, the increase in shipping and trading network also contributed largely to the dyeing trading.

Based on compelling evidence, indigo dyeing is a cultural skill practised in kano many years before the emergence of trade between both caravans of North-African Arab traders as well as European merchants (Baikie, 1864; Consular report, Tripoli, 1891-7; Consular report, Tripoli, (1896-7; Vischer, 1910; Bovill, 1933 \& 2018; Caillie, 1965; Boahen, 1964; Barth, 1965; 
Newbury, 1966; Hiskett, 1966; Hallett, 1968; Brenner, 1971; Hopkins, 1973 \& 2019; Johnson, 1976; Field Data, 2018).

Unbleached calicoes brought in from Manchester by caravans of Arab traders, and locally woven fabrics were dyed using that skill, before being exported to other areas of the SubSahara regions and Europe (Johnson, 1976). Besides Kano, other lands of Hausa such as Zaria, Sokoto, the Kwararafa kingdoms, and people from the western part of Nigeria learned and practised this cultural skill. The Kofar Mata dyeing pits eventually came to light when the caravans of North-African Arab arrived with the purpose of religious mission and trade. Although the initial objective of dyeing was fundamentally meant for ceremonial purposes, such as festivities within the region, it became an industrial domain years later for many people in Kano and other parts of the Hausa land (Gausa, 2013). The origins this development could be traced to Caliphate period of Othman Dan Fodio in the northern region. The Caliphate stopped the use of the foreign suits among the population and ordered the use of locally dyed clothes among his subjects (both as administrative and day-to-day regalia) irrespective of individual ethnic affiliation (Candotti, 2015).

\section{Conservation Challenges Faced in Kofar Mata ICH Dyeing Industry in Kano}

Morris and Travis (1992) stressed that despite the widespread practice of ICH dyeing, it still remain a conservative skill in among the people in the community. As literatures shows that is one of the oldest human activities and means of livelihood for the vast majority of the people in Kano community, dyers in Kofar Mata dye pits had not caught up to current development of modern dyeing, both in methods and pattern designs (Dutsenwai, 2010). The challenges faced by dyers since the emergence of the Industrial Revolution, which resulted in some perspectives as stated in content, displayed in the Table 1.

Table 1: Challenges faced by dyers

Indigenous Technology

Youths attitude towards ICH dyeing skill

Dyers Challenges at Kofar Inadequate or lack of financial support

Mata ICH Dyeing Pits Lacks knowledge sharing and skill acquisition training

Climate Change

\section{IndigenousTechnology}

Craftsmen in the dyeing industry were slowly losing their skills to the modern mechanised textile industries. Findings from the study illustrate that low-technology method as suggested by Comlekcioglu et al., (2015) has negative consequence in the declining status of traditional dye industries that undermined the conservation and preservation of the sociocultural and socioeconomic heritage power resulted in unwarranted unemployment in most parts of Kano state community and economic loss. Numerous reports had been published on socio-political effects of the widespread unemployment in Kano and Nigeria (Asogwa, Umeh \& Okwoche, 2012; Bankole, 2013). In addition, findings of the study indicate that, the indigenous technologies in use in ICH dyeing Kofar Mata are old and finds it difficult to handle, that's why the at times these are referred as older generation skill by (Li et al., 2019). 


\section{Youth's Attitude toward Kofar Mata ICH DYE Skill Practice}

One other challenge faced by dyers in the conservation of the $\mathrm{ICH}$ dyeing skill practices and growth of the industry is the youth's attitude toward Kofar Mata ICH dye skill practice. Some youths in Kofar Mata community prefer to engage in the modern type of dyeing techniques. The youths consider the ICH dyeing in Kofar Mata as a tedious vocation to participate in unlike the synthetic dyeing method that is less tedious, the chemicals are readily available and is fast and easy to dye. The further emphasized that this has characterized the change in values and sense of fashion among the younger generation. There is lack of consistent encouragement by dyers in engaging their children to take up the ICH dyeing skill practice. This issue has also been reported by Li et al (2019) in their study in Yunnan, China explained that this is due to the fading frequency in the indigo dyeing industry and its associated knowledge. It is also noted that no appropriate effort to train the younger generation to replace those that passed away as suggested in the works of (Yang et al., 2018; Sandgrber et al., 2019; Lupu et al, 2016). This pause a great danger to the existing community-based cultural heritage, where the custodian of the community heritage is entrusted on them, as flag bearers as warned by (Aikawa-Faure, 2014). The loss of these LHT without replacement by new generation -could be consequential to the heritage skill practice and the industry. This is a true assertion by experts that the dead of experts dyers in Kofar Mata ICH dye pit, would be a colossal danger and threat tendencies of the disappearance of the ICH if the few or only custodian remaining dies out (Ahmad, 2006; Smeets, 2009; and Graciela, 2011).

\section{Inadequate or Lack of Financial Support}

One notable barrier to dyers as revealed during the study investigation was the inadequate or lack of financial support faced by the dyers in Kofar Mata ICH dyeing industry, according to Rusu (2011). Even though there are assertions of the authorities support, until today there is no significant or major achievement. Unclear support from the interest groups both state, national and non-governmental organization form part of the deteriorating welfare status of the dyers and gradual absence of competitive production in the potential heritage industry as postulated in (Grigg et al., 2020; Houessou et al., 2020).

\section{Lacks Knowledge Sharing and Skill Acquisition Training}

Kofar Mata ICH dyeing is the most acknowledged cultural identity in the state, but the deteriorating situation of the industry is also attributed by the inadequate knowledge sharing and skill acquisition training especially for the apprentice at dyeing pits (Shimray and Ramaiah, 2020) and those new into learning the ICH dyeing skill. Polanyi and Sen (2009) in their assertion stated that the Kofar Mata ICH is one of the tacit dimension of knowledge in the community which need tacit dimension of training, one-on-one on site training. This demonstrate the dynamism it brings to the creativity and innovativeness as a result knowledge sharing in the community-based cultural heritage knowledge, fallen short to demonstrate this tacity, the much expected growth maybe not be feasible, emphasized (Polanyi and Sen, 2009).

\section{Climate Change}

Climate change is also a challenge that cannot be left out in the discourse. This environmental factor like globalization is part of major threat militating against that is short changing development of $\mathrm{ICH}$. For instance, some informants revealed that shortage or inadequate supply of raw material is one of the daunting challenges of the $\mathrm{ICH}$ dyeing pit at Kofar Mata 
as Dey (2010); Mishra (2021), and Hawkins, Sharrock and Havens (2008) indicated in their studies. The context of cultural change forces the overbearing of globalization that is advocating for uniformity of culture despite the cultural diversity that is embedded in various world communities as emphasized in the works of (Appadurai, 1996; Benedict Anderson, 2006)

\section{Methodology}

This study employed a case study design approach to conduct a holistic investigation at Kofar Mata ICH dyeing pits (Liamputtong, 2017; Yin, 2009). Kofar Mata heritage site Kano was the study location, Kano state. The empirical data was collected through the in-depth interview, focus group discussion and on-site observation technique. Relevant documentaries, records and impirical past studies were also reviewed. These gave the researcher vivid pathological phenomenal situations of the dyers challenges. The outcome of the analysis from these secondary data is presented above to display the challenges faced by the dyer.

Prior to the data collection, there were few sites visit. This was carried out to make earlier contact with the dyers, and this strategy help in creating a good relationship with them. The good rapport between the researcher and researched encouraged them to share their experiences in a comfortable mood in the three months data collection period. A total of 12 informants were selected purposively through a snowballing sampling technique. Six of them were the key actors (i.e dyers), and the other six were informants from various sectors such as, authority people, academicians, and consumers. The first group was in-depth interviewed, and the second group engaged in the focus group discussion. The in-depth interview with the dyers were carried out at the site during their free time, and some interviews were carried out at their homes, after work. Each interview session is followed by transcription; and before the next interview the researcher make reference to what was not satisfactorily answered to be emphasised in the subsequent session. Each interview last for one hour thirty minutes to three hours, and a few were revisited to complete the interview. The interviews were tape-recorded with their consent. Since the dyers are small in numbers, and gone through more or less a similar experience, the size of six is the saturation point for them. Prior to the interview, a set of guideline questions was developed that covers dyers involvement dyeing activity that touches on their production and marketing, as well as the challenges they faced.

For the second group, FGS was employed. The discussion was focussed on their perception, consumer behaviour towards the dyeing activity as well as the acceptability of the product. This discussion was being held in Kano State History and Culture Bureau Board Room. This session was also tape recorded with their permission.

All recorded sessions were then transcribed, and followed by the coding process, and subsequently sub-themes and themes were developed and assigned to the respective analysed data. In fact data were pre-analysed during and between the interviews session in which the validation process within and between inteviews were also carried out. In other words the triangulation process between different data source that is between interviews took place simultaneously, and then triangulate with data from th FGD session. 


\section{Findings and Discussion}

There are six themes generated from the analysed indepth interviews and focus group discussion data as shown in Table 1 below. The theme are laballed as "Possible Strategies to Conserve the $\mathrm{ICH}^{\prime \prime}$ and the subthemes as shown below.

Table 1.2: Themes on the possible strategies to conserve the $\mathrm{ICH}$

Improvision of locally modernize technology

\section{Possible Strategies to conserve the intangible cultural heritage dyeing at Kofar Mata}

Enlighten the youths \& the public on ICH

Goverment intervention for soft loan scheme

Synergy among LHT \& academics

Proper registration \& recognition by authority

Legal framework to protect the territorial dimension as buffer zone

\section{Improvision of Locally Modernize Technology}

Empirical data from the study revealed that dyers at Kofar Mata are still wanting to continue participating the ICH business. The findings also show there is an consensus responses among informants on the imperative of $\mathrm{ICH}$ in safeguarding and promoting socio-cultural and socioeconomic norms of the people. However, based on the triangulated data, they agreed that the ICH dyeing business was actually facing with an inherited challenges of lowtechnology standard use in the process of production. Example of this heart complaint is shared below.

The practice is solemnly dying. Most of the technology we use are still those type used by our forefathers. [...] The younger generation are finding it difficult to cope with the use of these old traditional technologies. [...] As you can see most of the dyers are the older generation, [...] What am saying is that there should new improvised technologies better than the ones in use now that can easily be use by everyone especially the youths, to attract their involvement.

This assertion was affirmed across the informants that participated in the data collection. The was a general consensus of informants suggested that the community need a new innovation on the technology to be use to replace the old low-technology. The dyers calls for all stakeholders in the community to fully participate, expected to put their energy together to rescue the situation, to initiate for a sustainable locally made technology to enhance their production. This aspiration is also shared by past studies as suggested by Li, Cunningham, Fan, and Wang (2019) and Lupu, Tanase, Tudurache (2016) that suggesting new indigenous technology could propel local industry to another level.

\section{Enlighten the Youths \& the Public on ICH}

$\mathrm{ICH}$ reflect the people's own cultural identity. Preserving the heritage as part of the cultural capital could be carried out in many ways, and one of it is by enlightening the youth and the public. The finding revealed that the dyers is hoping for the concerted effort to raise awareness among to the youths about the present ICH dyeing knowledge which seems to be 
disappearing in many places, especially in Kano. Based on the triangulated data, informants are of the opinion that:

We seriously need the authority's effort here, only we dyers cannot do it alone, for instance, it's only the authorities that have the power of the media to disseminate information [to public..] so here we need their support, from youths. [..].

Besides, it is also worth to enlighten the youths on the comparable difference between the natural dye and the synthetic dye, for example, the toxicity and pollution content of the synthetic dye. Some literatures like Rachman, Bilkis and Hasbi (2020); Gapor, Abdul Rahman, Echoh and Rosli (2019) indicates that involving youths' participation in ICH dyeing is like bringing new innovation and creativity, because they youths have bright ideas and high spirit, to achieve goals. Educating the youth and the general public on the dyeing process by natural dye that is a concoction of varied plants that less harmful, anti-bacteria and are even of medicinal value as indicated by some scholars Mishra and Gautam (2020), Patil, et al (2016), and Geetha and Sumathy (2013) is part of preserving the local identity industry

\section{Authorities Intervention for Softloan Scheme}

There is need to soften the bureaucratic barriers between dyers and some financial institutions lukewarm attitude towards the heritage craftsmen. Based on the study findings informants suggests that there should be determined commitment by the authorities to tackle issue of this nature. Informants observed that:

\section{[...] We want the authorities to come in, because we are not being assisted by any financial institutions for any kind of soft loan, [...] that may augment our occasional situations[..].}

Incentivization does not necessarily come from the authorities, mostly comes from outsourcing, such as crowdsourcing or fundraising. These are other forms ameliorating the desperate situation faced by dyers after or during some collateral damages by rainstorm, flooding in some cases. Dyers having financial support in terms of soft loan will greatly improve their welfare and growth of the industry as supported by Houessou, et al., (2020). This approach is in line with the critical heritage studies conceptual ideas that both interest groups be it official or unofficial should play its role in the growth of both heritage practices (tangible or intangible) (Winter, 2014; Gentry and Smith, 2019; Smith, 2014; Coombe, 2010; Harrison, 2013).

\section{Synergy Among Living Human Treasures (LHT) and Academics.}

Synergy among LHT and academics is a mutual local force towards providing cultural sustainability to the ICH Kofar Mata dyeing industry. In this context the mutually beneficial role plays much in the area of $\mathrm{ICH}$ sharing knowledge experiences by the dyers. On the other hand, the academicians may work out an alternative natural indigo colour in the laboratory for dyers benefits. In the triangulated findings of the study the informants shared the same aspiration. Below is one of the example indicate the idea: 
If this is officially established, it will serve as a bridge between the dyers and the Academicians [...] at the same time, it will strengthen our knowledge sharing and improve our productivity of our colours and design.

This is one of the potential supportive initiative for conservation policies towards the growth of ICH Kofar Mata.

\section{Proper Registration and Recognition by Authority}

From the analysed FGD data, the informants recognised that dyers are the living heritage, and they need to be acknowledged by the relevant body. Informants viewed that there should be a registration of dyers as a formal medium to recognise their contribution to the nation, culturally and economically. Below is the verbatim displaying the concern.

Any society that wants progress cannot relegate such custodian of our heritage, Living Human Treasures (dyers) on the borderline. [...] so giving us due recognition through registration means the society recognizes our sociocultural and economic contributions even before and now[..].

This idea will mean a lot to the dyers. It is about a new drive for cultural preservation and sustainability for the community-based $\mathrm{ICH}$ industry. The registration would serve the prerequisite for its sustainable development as some scholars indicated in their studies such as Fanea-Ivanovici (2018), Poort et al., (2021) and Soini and Dessein (2016). Proper registration and recognition will give the necessary credibility and at the same time giving dyers a medium to voice in decision making processes concerning their welfare which also postulated by Li et al., (2021) and Nocca (2017) studies.

\section{Legal Framework to Protect the Territorial Dimension as Buffer Zone}

It was seen by the dyers that legitimization framework of the ICH heritage site as creating a buffer zone for them. The triangulated data from the study revealed that the dyers believed that this initiative is like giving the ICH Kofar Mata cover of legitimization in the sense give LHT a complete assurance, confidence and, to the community it means safeguarding for generations, as one of the informant said;

Making it lawfully binded territory for us, [..] that is no more encroachment into the site. The law will protect our dyeing pits and we (dyers) also, since we are not going to lose our vocational job, authorities will protect everyone and everything.

This idea is in-line with the contemporary strategies according to critical heritage studies theory concept where all interest groups bodies like state, UNESCO are involve in protection, promoting and safeguarding the Kofar Mata dyeing industry from total disappearance as opined by scholars like Lenzerini (2020), Lixinski (2011; 2013), and Lixinski and Blake (2020). Despite the purported neglect by the authorities and poor attitude of some youths towards the heritage practice, ICH dyeing still remains an integral part of Nigeria, Kano heritage identity. The present condition of the ICH heritage industry is not efficient for large production as it used to be, but this indigenous industry can be preserved as national heritage. 
Findings of the study suggest that continuous engagement community of dyers is due to the combination of sociocultural and economic factors being the main reason for them to continue working in the $\mathrm{ICH}$ industries in Kano. The socio-cultural factors from this study are found to be similar to Adeyemi and Bappah (2011), who claimed that the engagement of people in cultural heritage throughout modernisation is symbolic and essential to preserving the indigenous identity. Indeed, this study believed that the practice of socio-cultural heritage among the people in Kano despite the challenges faced is imperative and cannot be underestimated. The economic factor is highly based on the issue of employment, whereby findings from this study agrees to studies by Elsahida et al (2020) Bankole (2013) as well as Becker-Leifhold and Iran (2018). These studies have insisted that sustenance of cultural heritage, besides tourist attraction, will also guarantee a wide range of employment opportunities to the growing population.

The Kofar Mata dye pit has been acknowledged as a national monument and a symbol of UNESCO Universal Outstanding Value UOV (Labadi, 2013). If properly sustained, Kofar Mata can be a renowned tourist site in Nigeria that promotes the rich socio-cultural history of the local people. The awareness of socio-cultural identities and strong community cohesiveness can be built through the common shared value among the dyers and the community in Kano, confirming the arguments from various empirical studies.

Nevertheless, the ICH industry in Kano faced with numerous challenges, with the central issue of continuous neglect from the government. The government has yet to amend existing policies, such as restricting the import of cheap textile products into the country to support the $\mathrm{ICH}$ industry and wellbeing of the dyers. Due to inadequate support by the government, most skilled and experienced employees have either left the industry or are only involved half-heartedly. By and large, this suppressed the growth of ICH at Kofar Mata in Kano. If these dyers are not resilient enough to face these issues plus the development of modernised fusion of fashion designs that are attractive to young generation, this can result in an abrupt disappearance of the historic designs worn in the Kano land.

\section{Conclusion}

Dyers in Kofar Mata dye pit in Kano Nigeria are the Living Human Treasures (LHT). Although there is general understanding about the role and importance of the dyeing profession, adverse experiences expressed are challengers to the conservation effort of this Intangible Cultural Heritage (ICH). It is believed that culture defines the social identity of the community and the people. Those who forget about their culture will forget their history. This is the primary motives of dyers to preserve, protect and safeguard the Kano dyeing pits as the common heritage. Both parties should come together to conserve this national heritage. The dyers and the local young inidividuals can initiate local community workshop to raise awareness the importance of the indigenous culture and also hands-on training on the dyeing process as a continuous action. To ensure a good and marketable product, the dyers should keep up a good quality of production. More attractive traditional design and a fusion design can be introduced to capture not only for the local Nigerian market but also abroad. Last but not least is the government support in terms of legislation and monetary to boost the dyers as the Living Human Treasures specifically, and the community in Kofar Mata, Kano. 


\section{References}

Abisuga-Oyekunle, O. A., \& Fillis, I. R. (2017). The role of handicraft micro-enterprises as a catalyst for youth employment. Creative Industries Journal, 10(1), 59-74.

Adeyemi, A., \& Bappah, B. A. (2011). Conservation of Kano ancient city wall and gates: Problems and prospects in Nigeria. Journal of Environmental Issues and Agriculture in Developing Countries, 3(2), 80-92.

Ahmad, Y., (2006). The Scope and Definitions of Heritage: From Tangible to Intangible. International Journal of Heritage Studies, 12(3), 292-300.

Aikawa-Faure, N. (2014). Excellence and authenticity: 'Living National (Human) Treasures' in Japan and Korea. International Journal of Intangible Heritage, 9, 37-51.

Anderson, B. (2006). Imagined communities: Reflections on the origin and spread of nationalism. Verso books.

Appadurai, A. (1996). Modernity at large: Cultural dimensions of globalization (Vol. 1). U of Minnesota Press.

Asogwa, B. C., Umeh, J. C., \& Okwoche, V. A. (2012). Community Fishing and the Economics of Argungu Fishing Festival in Nigeria. Asian Journal of Business Management, 4(2), 192199. Available online: http://unesdoc.unesco.org/images/0013/001325/132540e.pdf (accessed on 19 April, 2019

Baikie, W. B. (1864). Public Record Office, in F.0./97/435.

Bankole, A. O. (2013). Harnessing Cultural Heritage for Tourism Development in Nigeria; Issues and Prospects. Global Journal of Commerce and Management Perspective, 2(3), 121-131.

Barau, A. S. (2007. An Account of the High Population in Kano State, Northern.

Barth, H. (1965). Travels and discoveries in North and Central Africa, three-volume ed. (London, 1965), 1, 517.

Bechtold, T., \& Mussak, R. (Eds.). (2009). Handbook of natural colorants (Vol. 8). John Wiley $\&$ Sons.

Becker-Leifhold, C., \& Iran, S. (2018). Collaborative fashion consumption - drivers, barriers and future pathways. Journal of Fashion Marketing and Management: An International Journal, 22(2), 189-208. doi:10.1108/jfmm-10-2017-0109

Blake, J. (2008). UNESCO's 2003 Convention on Intangible Cultural Heritage: the implications of community involvement in 'safeguarding'. In Intangible heritage (pp. 59-87). Routledge.

Blake, J., \& Lixinski, L. (Eds.). (2020). The 2003 UNESCO Intangible Heritage Convention: A Commentary. Oxford University Press.

Boahen, Adu. (1965): Britain, the Sahara, and the western Sudan, 1788-1861. (Oxford Studies in African Affairs.) xiii, 268 pp., 4 maps. Oxford: Clarendon Press, 1964. 35s. Bulletin of the School of Oriental and African Studies, 28(3), 670-670. doi:10.1017/S0041977X00071810.

Bovill, E. W. (2018). Caravans of the Old Sahara: An Introduction to the History of the Western Sudan, African Affairs, Volume XXXII, Issue CXXVIII, July 1933, Pages 328329, https://doi.org/10.1093/oxfordjournals.afraf.a100878

Brenner, L. (1971). 'The North African trading community in the nineteenth century Central Sudan', Boston University Papers on Africa, v, Aspects of African Islam (Boston, 1971), 148. 
Budiastuti, M. T. S., Purnomo, D., Pujiasmanto, B., \& Setyaningrum, D. (2021). Effect of light intensity on growth, yield and indigo content of Indigofera tinctoria L. In IOP Conference Series: Earth and Environmental Science (Vol. 724, No. 1, p. 012085). IOP Publishing.

Caillié, R. (1965). Journal d'un voyage à Timbouctou et à fenne, ii (Paris, 1965), 317.

Candotti, M. (2015) Cotton growing and textile production in northern Nigeria: from caliphate to protectorate, c.1804-1914. PhD Thesis. SOAS, University of London

Cohen, E. (2000). The Commercialized Crafts of Thailand Hill tribes and Lowland Villages; University of Hawaii Press: Honolulu, HI, USA.

Comlekcioglu, N., Efe, L., \& Karaman, S. (2015). Extraction of indigo from some Isatis species and dyeing standardization using low-technology methods. Brazilian Archives of Biology and Technology, 58, 96-102.

Coombe, R. J. (2010). Honing a critical cultural study of human rights. Communication and Critical/Cultural Studies, 7(3), 230-246.

Consular report, Tripoli, (1891-7). (F.O. Annual series Diplomatic and Consular 1022), 5.

Consular report, Tripoli, (1897) (F.O. Annual series, Diplomatic and Consular 2125), 14.

Consular reports, Benghazi, $(1896,1897)$.

Deacon, H., \& Smeets, R. (2018). Intangible heritage safeguarding and intellectual property protection in the context of implementing the UNESCO ICH Convention. In Safeguarding Intangible Heritage (pp. 36-53). Routledge.

Dey, D. (2010). Of Global Warming and Indigo Economy. The Frontier Weekly, August, 22-28.

Dutsenwai, S. A (2015). Indigenous Hausa Indigo Dyeing in Northern Nigeria, Multidisciplinary Journal of Research Development Vol. 15.5, 80-85

Eichler, J. (2021). Intangible cultural heritage, inequalities and participation: who decides on heritage? The International Journal of Human Rights, 25(5), 793-814.

Elsahida, K., Fauzi, A. M., Sailah, I., \& Siregar, I. Z. (2020, April). Sustainable production of natural textile dyes industry. In IOP Conference Series: Earth and Environmental Science, 472(1), IOP Publishing.

Fanea-Ivanovici, M. (2018). Culture as a prerequisite for sustainable development. An investigation into the process of cultural content digitisation in Romania. Sustainability, 10(6), 1859.

Feilden, B. (2003). Conservation of Historic Buildings (3rd ed.). Routledge. https://doi.org/10.4324/9780080502915

Foster, G., \& Saleh, R. (2021). The Adaptive Reuse of Cultural Heritage in European Circular City Plans: A Systematic Review. Sustainability, 13(5), 2889.

Gausa (2013). "An Adaptive Study of Jukun Cultural Symbols for Textile Design." Unpublished Master of Fine Arts (MFA) Thesis University of Nigeria Nsukka.

Gazzola, P., Pavione, E., Pezzetti, R., \& Grechi, D. (2020). Trends in the fashion industry. The perception of sustainability and circular economy: A gender/generation quantitative approach. Sustainability, 12(7), 2809.

Geetha, B., \& Sumathy, V. J. H. (2013). Extraction of natural dyes from plants. International Journal of Chemistry and Pharmaceutical Sciences, 1(8), 502-509.

Gentry, K., \& Smith, L. (2019). Critical heritage studies and the legacies of the late-twentieth century heritage canon. International Journal of Heritage Studies, 25(11), 1148-1168.

Gupta, V. K. (2019). Fundamentals of natural dyes and its application on textile substrates. Chemistry and technology of natural and synthetic dyes and pigments, 2019.

Hallett, R. (1968). Introduction to Bovill,E. W.,The Golden Trade of the Moors, 2nd ed. (London,1968), xi. 
Harrison, R. (2013). Forgetting to remember, remembering to forget: late modern heritage practices, sustainability and the 'crisis' of accumulation of the past. International Journal of Heritage Studies, 19(6), 579-595.

Harun, S. N. (2011). Heritage Building Conservation in Malaysia: Experience and Challenges. The 2nd International Building Control Conference 2011. Procedia Eng., 20, 41-53)

Hawkins, B., Sharrock, S., \& Havens, K. (2008). Plants and climate change: which future? Botanic Gardens Conservation International.

Heathcote, D. H. (1976). The Arts of the Hausa. World of Islamic festival Publishing Company Ltd.

Hiskett, M. (1966). 'Materials relating to the cowry currency of the Western Sudan', Bulletin of the School of Oriental and African Studies, xxix (London, 1966), part 1, $122 \mathrm{ff}$.

Hopkins, A. G. (1973 \& 2019). An Economic History of West Africa (1st ed.). Routledge. https://doi.org/10.4324/9781315835792

Houessou, M. D., van de Louw, M., \& Sonneveld, B. G. (2020). What Constraints the Expansion of Urban Agriculture in Benin? Sustainability, 12(14), 5774.

Inikori, J. E. (2009). English versus Indian cotton textiles: The impact of imports on cotton textile production in West Africa. In How India Clothed the World (pp. 85-114). Brill.

Ishrat, S. I., Grigg, N. P., Bezuidenhout, C. N., \& Jayamaha, N. P. (2020). Sustainability Issues in the Traditional Cashmere Supply Chain: Empirical Evidence from Kashmir, India. Sustainability,12(24), 10359.

Johnson, M. (1974). Cotton Imperialism in West Africa. African Affairs, 73(291), 178-187.

Johnson, M. (1976). Calico caravans: the Tripoli-Kano trade after 1880. The Journal of Africa History, 17(1), 95-117.

Kobayashi, K. (2019). Indian cotton textiles in West Africa: African agency, consumer demand and the making of the global economy, 1750-1850. Springer.

Kurin, R. (2004). Safeguarding Intangible Cultural Heritage in the 2003 UNESCO Convention: a critical appraisal. Museum international, 56(1-2), 66-77.

Kurin, R. (2007). Safeguarding intangible cultural heritage: Key factors in implementing the 2003 Convention. International journal of intangible heritage, 2(8), 9-20.

Labadi, S. (2013) UNESCO, Cultural Heritage, and Outstanding Universal Value: Value-based Analyses of the World Heritage and Intangible Cultural Heritage Conventions. Rowman \& Littlefield. USA: AltaMira Press.

Labadi, S. (2017) UNESCO, world heritage, and sustainable development: International discourses and local impacts. In Collision or Collaboration; Springer: Cham, Switzerland, 2017; pp. 45-60, ISBN 978-3-319-44515-1.

Leesuwan, V. (2010). Folk handicrafts: Local identity. Silpakorn Univ. J, 30, 163-182 Lenzerini, F. (2020). Intentional Destruction of Cultural Heritage. In The Oxford Handbook of International Cultural Heritage Law.

Li, S., Cunningham, A. B., Fan, R., \& Wang, Y. (2019). Identity blues: the ethnobotany of the indigo dyeing by Landian Yao (lu Mien) in Yunnan, Southwest China. Journal of Ethnobiology and Ethnomedicine, 15(1), 1-14. doi:10.1186/s13002-019-0289-0

Li, X., Kim, J. S., \& Lee, T. J. (2021). Collaboration for Community-Based Cultural Sustainability in Island Tourism Development: A Case in Korea. Sustainability, 13(13), 7306.

Liamputtong, P. (2017). Three day Seminar workshop in qualitative research, Organized by University Malaya, Malaysia. 
Lin, Q., \& Lian, Z. (2018). On Protection of Intangible Cultural Heritage in China from the Intellectual Property Rights Perspective. Sustainability, 10, 4369. https://doi.org/10.3390/su10124369

Lixinski, L. (2011). Selecting heritage: the interplay of art, politics and identity. European Journal of International Law, 22(1), 81-100.

Lixinski, L. (2013). Intangible cultural heritage in international law. Oxford University Press: OUP Oxford. United Kingdom.

Lovejoy, P. E. (2016). Jihād in West Africa during the age of revolutions. Ohio: Ohio University Press.

Lupu, N., Tănase, M. O., \& Tudorache, P. (2016). Quo Vadis" Living Human Treasures"? Amfiteatru Economic Journal, 18 (Special Issue No. 10), 757-766.

Mishra, A. K. (2021). "Plant Adaptation to Global Climate Change" Atmosphere 12, no. 4: 451. https://doi.org/10.3390/atmos12040451

Mishra, A., \& Gautam, S. (2020). Application of Natural Dyes for Herbal Textiles. In Chemistry and Technology of Natural and Synthetic Dyes and Pigments. IntechOpen.

Miura, K. (2005). Conservation of a "living heritage site" A contradiction in terms? A case study of Angkor World Heritage Site. Conservation and Management of Archaeological Sites, 7(1), 3-18. doi:10.1179/135050305793137602

Morris, P. J., \& Travis, A. S. (1992). A history of the international dyestuff industry. American Dyestuff Reporter, 81, 59-59.

Mustafa, S., \& Saleh, Y. (2017). An overview on intangible cultural heritage in Malaysia. International Journal of Academic Research in Business and Social Sciences, 7(4), 10531058.

Mustapha, A., Yakudima, I. I., Alhaji, M., Nabegu, A. B., Dakata, F. A. G., Umar, Y. A., \& Musa, B. U. (2014). Overview of the physical and human setting of Kano region, Nigeria. Research Journali's Journal of Geography, 1(5).

Nagy, J., Oláh, J., Erdei, E., Máté, D., \& Popp, J. (2018). The role and impact of Industry 4.0 and the internet of things on the business strategy of the value chain - the case of Hungary. Sustainability, 10 (10), 3491.

National Academy of Sciences (US) (1975). Committee on the Survey of Materials Science, National Academy of Sciences (US). Committee on Science, \& Public Policy. Materials and Man's Needs: Materials Science and Engineering; Supplementary Report. National Academies.

Newbury, C. W. (1966). 'North African and Western Sudan Trade in the Nineteenth Century: Nigeria. http://www.ciesin.columbia.edu/repository/pern/papers/Barau.pdf

Nocca, F. (2017). The role of cultural heritage in sustainable development: Multidimensional Indicators as decision-making tool. Sustainability, 9(10), 1882.

Oláh, J., Aburumman, N., Popp, J., Khan, M. A., Haddad, H., \& Kitukutha, N. (2020). Impact of Industry 4.0 on environmental sustainability. Sustainability, 12(11), 4674.

Patil, D. B., Patil, K. N., Gaikwad, P. V., Patil, P. J., Shewale, U. L., \& Bhamburdekar, S. B. (2016). Extraction of natural dye from rose flower for dyeing cotton fabrics. International Journal for Innovative Research in Multidisciplinary Field, 2(8), 135-37.

Polanyi, M., \& Sen, A. (2009). The tacit dimension. Chicago: University of Chicago Press.

Poort, M. E., Persson-Fischier, U., Martinsson-Wallin, H., Elf Donaldson, E., \& Schaub, M. (2021). "Authenticity" as a Pathway to Sustainable Cultural Tourism? The Cases of Gotland and Rapa Nui. Sustainability, 13(11), 6302. 
Roblek, V., Thorpe, O., Bach, M. P., Jerman, A., \& Meško, M. (2020). The Fourth Industrial Revolution and the Sustainability Practices: A Comparative Automated Content Analysis Approach of Theory and Practice. Sustainability, 12 (20), 8497.

Roders, A. P., \& van Oers, R. (2010). Outstanding universal value, world heritage cities and sustainability: mapping assessment processes. World Heritage and Cultural Diversity, 225.

Rusu, A. A. (2011). Traditional textile art between sustainability and economic growth. Copyright(C) 2011 Pro Global Science Association.

Sandgruber, R., Bichler-Ripfel, H., \& Walcher, M. (2019). Traditional Craftsmanship as intangible cultural heritage and an economic factor in Austria. BUILDING FUTURE COMPETENCES, 49.

Shimray, S. R., \& Ramaiah, C. K. (2020). Factors of influence on sharing of cultural heritage knowledge. VINE Journal of Information and Knowledge Management Systems. DOI 10.1108/VJIKMS-04-2020-0074.

Singer G.G., (2011). Published January online: http://terraeantiqvae.com/profiles/blogs/theimportance-of-the

Smith, C. (Ed.). (2014). Encyclopaedia of global archaeology. Springer Reference.

Smith, L. (2006). Uses of heritage. Routledge: London

Soini, K., \& Dessein, J. (2016). Culture-sustainability relation: Towards a conceptual framework. Sustainability, 8 (2), 167.

Stefano, M. L., Davis, P., \& Corsane, G. (Eds.). (2014). Safeguarding intangible cultural heritage (Vol. 8). Boydell \& Brewer Ltd.

UNESCO. (2019). Basic Text of the 2003 Convention for the Safeguarding of the Intangible Cultural Heritage

Vischer, H. (1910). Across the Sahara to Bornu (London, 1910), 148.

Winter, T. (2014). Heritage studies and the privileging of theory, International Journal of Heritage Studies, 20:5, 556-572, DOI: 10.1080/13527258.2013.79867

Yan, W. J., \& Chiou, S. C. (2021). The Safeguarding of Intangible Cultural Heritage from the Perspective of Civic Participation: The Informal Education of Chinese Embroidery Handicrafts. Sustainability, 13(9), 49-58.

Yang, Y., Shafi, M., Song, X., \& Yang, R. (2018). Preservation of cultural heritage embodied in traditional crafts in the developing countries. A case study of Pakistani handicraft industry. Sustainability, 10(5), 1336.

Yin, R. K. (2009). Case study research: Design and methods. London: Sage 